\title{
Diagnostic virology and patient care: from vaguely interesting to vitally important
}

Sarah J. Pitt \& D. Ian M. Phillips

\section{ABSTRACT}

The existence of pathogenic viruses was inferred by experiments at the turn of the twentieth century. Key developments in detection of viruses, including electron microscopy and monolayer cell culture, were made in the middle of that century. However, in terms of patient care, the results from the virology laboratory often arrived the patient was 'better or dead'. The advent of molecular techniques, particularly polymerase chain reaction and more recently whole genome sequencing made timely and accurate diagnosis of viral infections feasible. A range of approaches have been taken to identify and characterise new viruses. Vaccines against viruses have made it possible to eliminate two pathogenic mammalian viruses altogether, with several others close to eradication. The role of biomedical scientists working in diagnostic virology is more relevant to patient care than ever.

\section{Introduction}

Advances in the resolution of light microscopes in the seventeenth century, and the observations made by pioneers such as Hooke and van Leeuwenhoek, led to the realisation that there are organisms which cannot be seen by the naked human eye ('little animalcules').[1] In the 1860s, once Pasteur had demonstrated that these microscopic organisms did not generate spontaneously, he was able to propose the 'germ theory' of disease.[2] Building on this, during the late nineteenth century, bacteria and parasites isolated from plant, animal and human samples, were observed microscopically, described and classified. Once it was possible to culture these micro-organisms in vitro, then the method ('postulates') for proving the link between a particular organism and a clinically described infectious disease was developed by Koch.[2] Thus, the role of clinical and diagnostic microbiology in making a useful contribution to patient care and public health was established.

However, it was observed that there were some pathogenic organisms which could pass through conventional filters ('filterable viruses'), but could not be detected by light microscopy and were therefore clearly smaller than bacterial cells.[2] Ivanovsky is credited with discovering and documenting the first of these - Tobacco Mosaic Virus - in 1892. The earliest noted connection made between a human disease and one of these 'viruses' which evaded filtration was for yellow fever in 1900.[3]

However, the real significance of viruses as pathogens was not recognised before the advent of the electron microscope and cell culture techniques to grow them in the laboratory in the 1950s. A book about 'microbes' written for the lay reader in the early 1940s [4] included the following:

In a highly civilised country, situated in a temper-ate zone, such as England, the Bacteria are probably more important incitants of human disease than the Ultramicroscopic Viruses, although these are responsible for many serious infections of man.

The latter half of the twentieth century saw virologists' workloads expand sufficiently for it to become a separate pathology discipline, and it is now recognised that viral infections are responsible for significant mortality and morbidity worldwide. Viruses are associated with not only acute, mild self-limiting diseases such as the common cold (Rhinoviruses), but with chronic debilitating infections (including Hepatitis B Virus and Hepatitis C Virus), epidemic and pandemic infections (Influenza A) and new and emerging infections (Human Immunodeficiency Virus, Ebola Virus, Zika 
Virus). Damage caused by viral replication processes and the host's immune response to the infection can also lead to long-term sequelae. It has been estimated that in about $16 \%$ of people diagnosed with cancer worldwide, the malignancy is attributable to an infection, which may have been acquired many years previously.[5] Analysis of global data from 2008 suggested that of the 12.7 million newly diagnosed cancers, about 610,000 were attributable to infection with Human Papillomavirus and 60,000 to Hepatitis B and/or C. These were the second and third most common infectious causes, behind Helicobacter pylori, which was recorded in 660,000 cases.[5] Table 1 provides epidemiological data about selected viral infections for the United Kingdom. This illustrates the nature of the work and the workload of diagnostic virology laboratories. The incidence data given in Table 1 are the approximate number of new, laboratory confirmed cases recorded each year. The number of samples tested will be several times that number, but the demand for testing may vary slightly depending on the epidemiology of the virus. Respiratory syncytial virus (RSV) is an important cause of severe infection in young children (most commonly bronchiolitis) and the elderly (pneumonia; flu-like illness). It is a seasonal infection, with a peak in December/January and incidence also varies between years. This means that the demand for RSV investigations on respiratory samples is always highest at the start of the year, but the numbers of tests which will be performed each year is not necessarily predictable. The annual incidence of measles in the UK also varies (Table 1) and recent outbreaks have tended to be focussed in particular geographic areas. During the first half of 2012, there was an outbreak centred around Merseyside, during which 1339 people were identified as possibly having the infection.[6] Laboratory investigations were conducted on samples from 881 of them. Evidence supporting the diagnosis of acute measles (anti-measles IgM) was found in 359 patients' saliva, throat swab or urine, which was $39 \%$ of probable or possible cases. [6] Hepatitis B Virus (HBV) is a major cause of morbidity and mortality globally. At least 240 million people are thought to be chronic carriers of the virus and over 600,000 deaths are attributable to the consequences HBV infection (fulminant hepatitis, liver cirrhosis, hepatic cancer) each year.[7] Routine screening for Hepatitis B Virus (HBV) infection is carried out on people from a range of demographic groups. These include intravenous drug users (who would be at a relatively high risk of infection) and pregnant women (very few of whom would be expected to be carrying the virus unwittingly). Nevertheless, since the overall prevalence of HBV in the UK is $<0.1$ per 100,000 of population,[7] finding a blood sample in which the HBV surface anti-gen is detected is not usually a daily occurrence for a diagnostic virologist. However, a positive test does create considerable amount of work, in terms of testing for HBV markers at the time of first diagnosis and following up that patient regularly to monitor the course of their hepatitis. Anti-viral therapy is also available for some persistent or recurring infections. In such cases, the efficacy of the treatment would be assessed through monitoring of the 'viral load'. Although many countries have a pol-icy of universal vaccination against $\mathrm{HBV}$, in the UK the programme is targeted to those at particular risk. This includes health care workers, including pathology laboratory staff. Post vaccination, recipients' blood is tested in the virology laboratory to ensure that their levels of anti-HBV antibody have achieved and maintained the recommended protective level of $100 \mathrm{mlU} / \mathrm{mL}$.[8-11] While the estimated prevalence of Hepatitis C Virus (HCV) in the UK is around 214,000, (Table 1) this figure is a projection which includes people who are asymptomatic and undiagnosed.[12] About 86,000 people are being treated for chronic infection with HCV.[12] These patients should all be receiving regular tests for the presence and level of HCV RNA in peripheral blood ('viral load'), to ascertain whether the treatment is achieving and maintaining a sustained viral response (SVR). Virology laboratory professionals have also risen to the challenges presented by viruses being discovered or changing their epidemiology. This includes development of diagnostic tests and development of protocols for handling of samples for patients potentially infected with unfamiliar viruses. In the 1980s Human Immunodeficiency Virus (HIV) went from an unrecognised virus, to the cause of a feared and fatal 
infection, to the current situation where diagnosis should lead to effective anti-retroviral therapy, resulting in a reasonably long and healthy life. The focus of the laboratory work related to HIV has also changed. At the start of the epidemic, blood samples for testing were regularly received from the 'worried well' due to the media publicity around HIV/AIDS. In the twenty-first century, there is more emphasis on identifying people with the infection and then monitoring them during treatment.[13] The ongoing outbreak of Ebola Virus (EV) in West Africa which began in 2014 [14] posed a different set of problems for UK virology laboratory scientists. The public health emergency situation continued until March 2016, by which time over 28,000 people had been diagnosed with Ebola in Sierra Leone, Guinea and Liberia and over 11,000 had died.[14] Test requests received from patients whose travel history suggests that they might have Ebola requires safe handling of the samples and sending them to the reference laboratory for testing. The number of confirmed cases among people in the UK is very small, however the knowledge and expertise gained through working with other blood borne viruses meant that UK virologists were well placed to design test kits and then work with colleagues in the areas affected by EV to set up field laboratories.[15] These examples illustrate how virology as a pathology discipline has been at the fore-front of laboratory technology, exploiting and driving innovation to aid the diagnosis, discovery and elimination of viruses.

\section{Role of laboratory virology in health care}

This article will use some examples to explore these three roles which virology plays within health care. Information was gathered by conducting a literature search using Google Scholar as a search engine. The keywords used were: diagnosis, discovery, elimination and names of the specifically selected laboratory techniques and virus examples. Articles were assessed for their relevance to the topics under consideration in each paragraph and any which were not freely available were excluded.

\section{Diagnosis}

By the 1980s, it was possible to culture many viruses of human importance in the laboratory using chick egg or monolayer mammalian cell culture. Isolates could be identified to species level on the basis of their characteristic cytopathic effect (CPE) - or haemadsorption followed by transmission electron microscopy (EM) where no CPE was observable. Further discrimination was possible by detecting viral glycoproteins, using antibodies in techniques such as immune electron microscopy, immunofluorescence, and haemagglutination inhibition. The problem was that the effects on the cells usually took several weeks to become detectable. For example, although Herpes Simplex Virus produces CPE within 24-48 h,[16] for its close relative Varicella Zoster Virus, the very distinctive CPE takes about 21 days to develop.[17] A more rapid result could be obtained through direct detection of viruses, for example EM of vesicular lesions. Unfortunately, HSV and VZV particles appear the same (Figure 1), so further investigations would be needed to definitely distinguish between the two species.[16, 17] This technique was also routinely used to examine faecal samples, since a wide range of viruses could be identified by their EM appearance, including Norovirus (Figure 2). However, the limit of detection is 106 particles per gram, the instruments are expensive to buy and maintain and - as with other microscopic techniques - only one sample can be examined at a time.[18] Methods using fluorescent-labelled antibodies, raised against viral proteins expressed in infected host cells, are also available for a relatively quick result.[16, 17] This is also used in diagnosis of viruses such as RSV in respiratory specimens (Figure 3). While it is extremely useful in some situations, problems with immunofluorescence include lack of adequate cellular material in the sample, limited range of available labelled antibodies and the requirement for a fluorescence microscope. The other option for diagnosis was detection of specific serum antibody generated in 
response to the viral infection. The main-stay of this was the complement fixation test, which had the advantage of being applicable to many infectious agents, but the disadvantage of relying on measuring a change in antibody titre between the acute phase of the infection and the convalescent stage 14 days later, due to low sensitivity.

The introduction of molecular genetics techniques such as in situ hybridisation into diagnostic pathology allowed for more rapid and sensitive testing for some pathogens, for example the detection of Parvovirus in hydrops fetalis [19] and Human Papillomavirus in cervical smears.[20] However, the invention of the polymerase chain reaction (PCR) $[21,22]$ eventually led to a complete change in diagnostic virology since it is more sensitive and specific than culture and/or microscopy $[23,24]$ and can provide the result more quickly.[25] As more lab-oratories use PCR, the cost of reagents has fallen and automated systems have been created making it possible to process large batches of samples, testing for a range viral pathogens. There has also been an added benefit to animal welfare, since several widely used cell lines were derived from primary monkey kidneys. The loss of the 'catch all' advantage of the older techniques can be offset using multiplex PCR [26] such as those available for respiratory viruses.[27, 28] It can be used to detect DNA viruses, such as adenovirus and rotavirus in children with gastroenteritis symptoms [29] or RNA viruses - via reverse transcriptase PCR - including enteroviruses in children with aseptic meningitis.[30] Quantitative methods such as TaqMan [31] and Real Time [32] were designed, thus allowing measurement of viral load. This can be important in monitoring response to anti-viral treatment in, for example, acute influenza,[32] chronic Hepatitis C [33] or post-transplant Cytomegalovirus [34] infections. Sequencing of the PCR products is also invaluable, for example for monitoring prevailing influenza and RSV strains,[35] Norovirus strain divergences during an outbreak [36] or detecting low copy number ('occult') or mutant HBV variants which might not be picked up by other diagnostic tests.[37]

The advent of radio - and enzyme- immunoassays (RIA and EIA), particularly using monoclonal antibodies changed viral serology. It became feasible to detect IgG and IgM separately instead of 'total' antibody, which allowed earlier detection of acute infection and also confirmation of whether the patient had protective antibodies. For example, it is therefore possible to determine whether a child presenting with a red rash has measles (detectable levels of IgM against that virus) or preexisting IgG antibodies (probably attributable to the MMR vaccine), which would exclude Measles Virus as the causative agent.[38] Serological tests could then be adapted to capture serum antigens, such as Hepatitis B surface antigen.[39] By the late 1990s, the 'fourth generation' tests for the presence of HIV were designed to detect a combination of anti-gp41 and anti-p24 antibodies and p24 antigen [40] in blood samples. This effectively reduced the 'window' between infection and diagnosis from the original 3-6 months quoted to patients in the 1980s, to around four weeks.[40] This antigen detection format has been adapted to other sample types, for example testing for Norovirus in faeces.[41] The EIA principle has been applied to immunchromatographic point of care (POCT) kits such as the ones for rapid testing of stool samples for Norovirus (Figure 4). They can be set up to detect more than one analyte. For example, there are POCT assays which can detect both IgM and IgG against Dengue virus [42] although for the timeliest diagnosis, it is recommended that such a kit should be used in conjunction with one which can detect the viral NS1 antigen.[42] Similarly, there are POCT kits set up to detect Influenza A (including pandemic strains) and Influenza $B$ in one test strip.[43] However, in general, the POCT kits are expensive compared to laboratory based assays and the antigen detection formats in particular often have less than ideal sensitivities, which means a definitive diagnosis often requires the support of the main virology laboratory. 
Molecular genetics methods and automation have also made screening programmes viable - for example the National Chlamydia Screening Programme.[44] Virologists are currently exploring the applications for the latest techniques of whole genome and next generation (or 'deep') sequencing (NGS) within their discipline, as analytical systems become commercially available. [45, 46] For example NGS is being applied to sequencing of HIV and HCV isolates to understand evolution of the virus within and between patients and monitor the development of resistance to anti-viral drugs.[47, 48] Similarly, it has been used in epidemiological investigations of Influenza A virus. [46] It has the potential to determine which particular strains of HIV express the glycoprotein structures which permit (or inhibit) binding to specific host cell receptors ('co-receptor tropism'); this could help to inform decisions about which anti-retrovirals to use in a particular patient.[46, 47] There are some technical and scientific issues, especially with sensitivity. Clinical samples contain human tissue, which means that both viral and human genomic material are sequenced and this inevitably generates a lot of data.[45] Also where there are several strains of one virus, the one present at the lowest copy number may not be readily detected.[48]

The service which diagnostic virology laboratories can offer has therefore been transformed from providing confirmation that the patient had a viral infection - sometime after they have died or recovered - to detection of viruses before the person develops symptoms.

\section{Discovery}

During the twentieth century, virologists were able to utilise the most up to date laboratory methods and equipment to discover new viruses. For example, Hepatitis B Virus was found somewhat serendipitously by Blumberg in the late 1960s.[49] He was using agar gel diffusion to investigate genetic polymorphisms in patients' serum, as part of an investigation into possible inherited susceptibility to disease. Instead, he discovered a reaction between what later transpired to be samples from a chronic Hepatitis B virus carrier and someone who had recovered from the infection - and therefore had specific antibodies.[49] The virus was subsequently visualised by Dane and colleagues, using what was then the very mod-ern, powerful and specialist tool of EM to examine serum. [50] The Parvovirus B19 was discovered by Cossart and colleagues a few years later. They were following up the Hepatitis B work and also investigating patients' sera by EM,[51] but unexpectedly found an unrelated virus. In contrast, the HIV was isolated from human blood samples through the diligence and well-designed experiments of Montagnier and Barré-Sinousi and their team [52] who were working to find the causative agent of Acquired Immune Deficiency Syndrome (AIDS). They used a combination of suspension cell culture and advanced molecular viral genetics to find the virus in human white blood cells and characterise it. Interestingly, the widespread use of routine viral culture led to the recognition of a group of viruses, usually found in faecal samples from children, which could not be linked to a definitive clinical syndrome. The so-called Enteric Cytopathic Human Orphan (ECHO) viruses are now known to be a com-mon cause of acute, mild, self-limiting febrile illnesses, although they are occasionally associated with more serious conditions such as viral meningitis, myocarditis and conjunctivitis.[53] The opposite occurred in the identification of Hepatitis $C$ virus as the cause of most 'non- $A$, non- $B$ ' hepatitis. Although a viral cause had long been suspected, it had not been found. The presence of immunogenic viral proteins was determined through animal experiments (and application of Koch's postulates). Recombinant peptides were prepared from these sequences from which c-DNA clones were made.[54] This allowed the development of a serological test for antibodies against these viral proteins,[55] before the whole virus had been isolated, visualised and fully characterised [56] and classified as Hepatitis C. Research and diagnostic virologists continue to be challenged to respond to new viruses, including Middle East Respiratory Syndrome Coronavirus 'MERS-CoV' $[57,58]$ and emerging viruses, exemplified by the 
outbreak of Ebola in 2014-2015.[15, 59] Molecular genetic techniques such as next generation sequencing are powerful and robust enough to contribute to virus discovery.[45]

\section{Elimination}

Two pathogenic infectious agents have been deliberately eradicated from the world and both are viruses, namely Smallpox Virus in 1980 [60] and Rinderpest Virus in 2011 [61] Advances in cell culture techniques, safety of medicines and understanding of micro-organism biology during the twentieth century made it possible for vaccines to be developed, tested and implemented into mass control campaigns. Many of these vaccines are against viruses. Optimistic from the success of the Smallpox work, in 1988 the World Health Organisation (WHO) set a target for eradication of polio (for which there are two types of vaccine available) by 2000 . Vaccination programmes have led to interruption of transmission of the virus in most countries and the number of cases has reduced by $99 \%$ from around 350,000 each year in the late 1980 s to less than 100 by the mid 2010s. [62] It is still endemic in three countries, namely Afghanistan, Nigeria and Pakistan, with outbreaks occurring sporadically in several others. [62] However, its elimination remains a realistic possibility. Thanks to the surveillance and sequencing work undertaken by laboratory virologists, the distinction between wild-type and vaccine-derived polio can be made and it is known that Poliovirus type 2 is no longer circulating - and it has therefore been removed from the vaccines.[62] For diseases like malaria and tuberculosis, the current strategy is reduction in mortality and morbidity rather than prevention of infection altogether. However for viral infections including measles and con-genital rubella, the WHO views the outright removal of the pathogen as a feasible aim.[63]

\section{Conclusion}

Thus, in less than a hundred years, diagnostic virology has moved from a situation where the laboratory work was very specialised and difficult to undertake (and probably not really needed) to one where biomedical scientists who are virologists play a vital part in patient care and public health (as shown in the $2009 \mathrm{H} 1 \mathrm{~N} 1$ influenza A pandemic and the 2014-2015 Ebola outbreak). There is now a better understanding of virus biology and the pathogenesis of viral infections, as well as the host immune response, than there was 50 years ago. The molecular genetics techniques available for diagnosis, strain differentiation of isolates and discovery of new viruses have the potential to contribute to the rapid development of anti-viral agents and vaccines. Point of care kits mean that it is possible to test yourself for viral infections such as HIV [64] in your own home, within minutes!

\section{Acknowledgements}

The authors would like to thank Ms C Dedi and Dr A Gunn for comments on drafts of this article.

\section{Disclosure statement}

No potential conflict of interest was reported by the authors.

ORCID

Sarah J. Pitt http://orcid.org/0000-0002-9215-6517

Table 1. Epidemiology of selected viral pathogens of humans in the United Kingdom. 


\begin{tabular}{lccc}
\hline Virus & $\begin{array}{l}\text { Approximate annual } \\
\text { incidence }^{\text {a }}\end{array}$ & $\begin{array}{l}\text { Estimated } \\
\text { prevalence }\end{array}$ & $\begin{array}{l}\text { Mortality } \\
\text { (average } \\
\text { deaths per } \\
\text { annum) }\end{array}$ \\
\hline Hepatitis B virus & 1000 & 180000 & 500 \\
\hline Measles virus & $500-2000^{c}$ & $\mathrm{~N} / \mathrm{A}^{\mathrm{e}}$ & $<1$ \\
\hline Human immunodeficiency & 6000 & 100,000 & $500^{\mathrm{d}}$ \\
\hline Virus Respiratory syncytial & $10-12,000^{\mathrm{c}}$ & $\mathrm{N} / \mathrm{A}$ & 80 \\
\hline Virus Norovirus & 15,000 & $\mathrm{~N} / \mathrm{A}$ & $100-200$ \\
\hline Hepatitis C virus & 18,000 & 214,000 & 400 \\
\hline Genital herpes simplex virus & 32,000 & $\mathrm{~N} / \mathrm{R}^{\mathrm{f}}$ & $\mathrm{N} / \mathrm{A}$ \\
\hline
\end{tabular}

Data collated from several sources [55-58]. A Laboratory confirmed new cases; b where recorded, for chronic infections; $c$ annual incidence varies; $d$ approximately $50 \%$ of deaths AIDS-related; e not applicable; $f$ data not recorded.

Figure 1. Showing a particle*. Source: Figure provided by Mr I Phillips. *it is not possible to identify species from EM appearance.

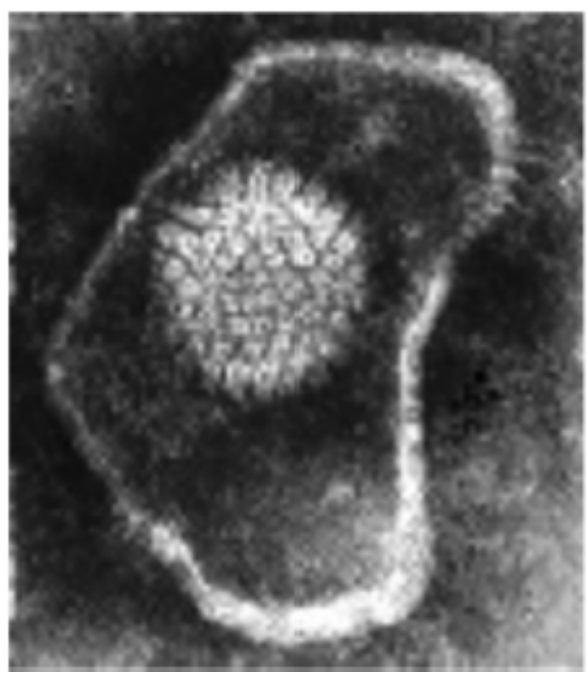

Figure 2. Electron micrograph of faecal sample showing norovirus particles. Source: Figure provided by Mr I Phillips.

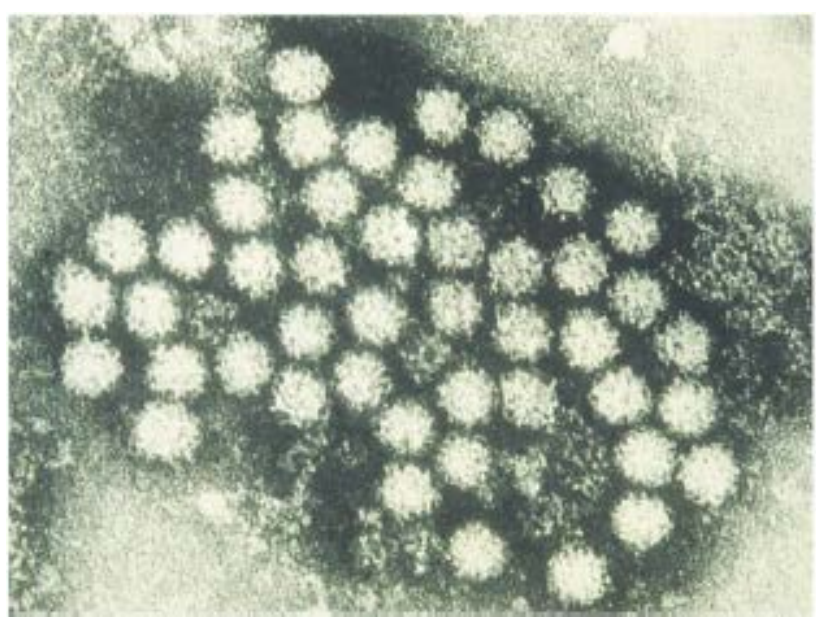


Figure 3. Fluorescence microscopy slide showing respiratory cells infected with RSV. Source: Figure provided by Mr I Phillips.

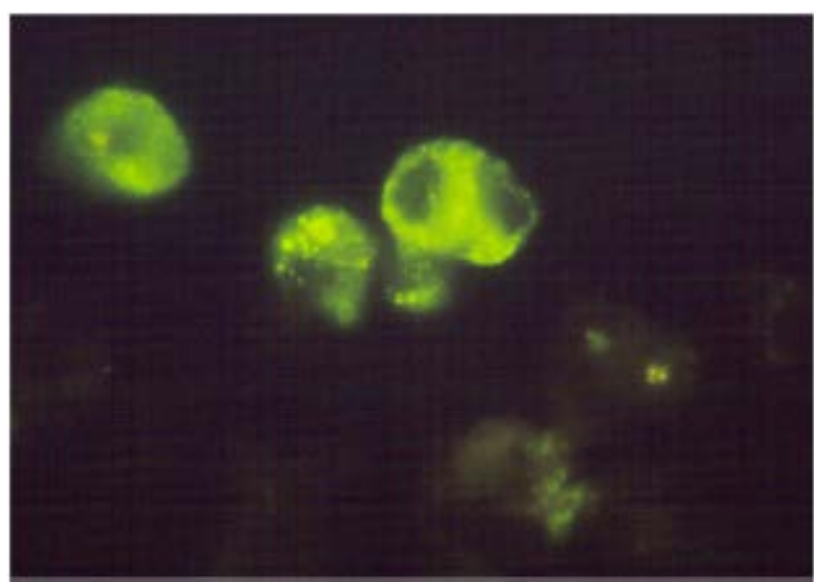

Figure 4. Point of care device to test for norovirus antigen in faecal samples (negative result). Source: Figure provided by $\mathrm{Dr} S$ Pitt.

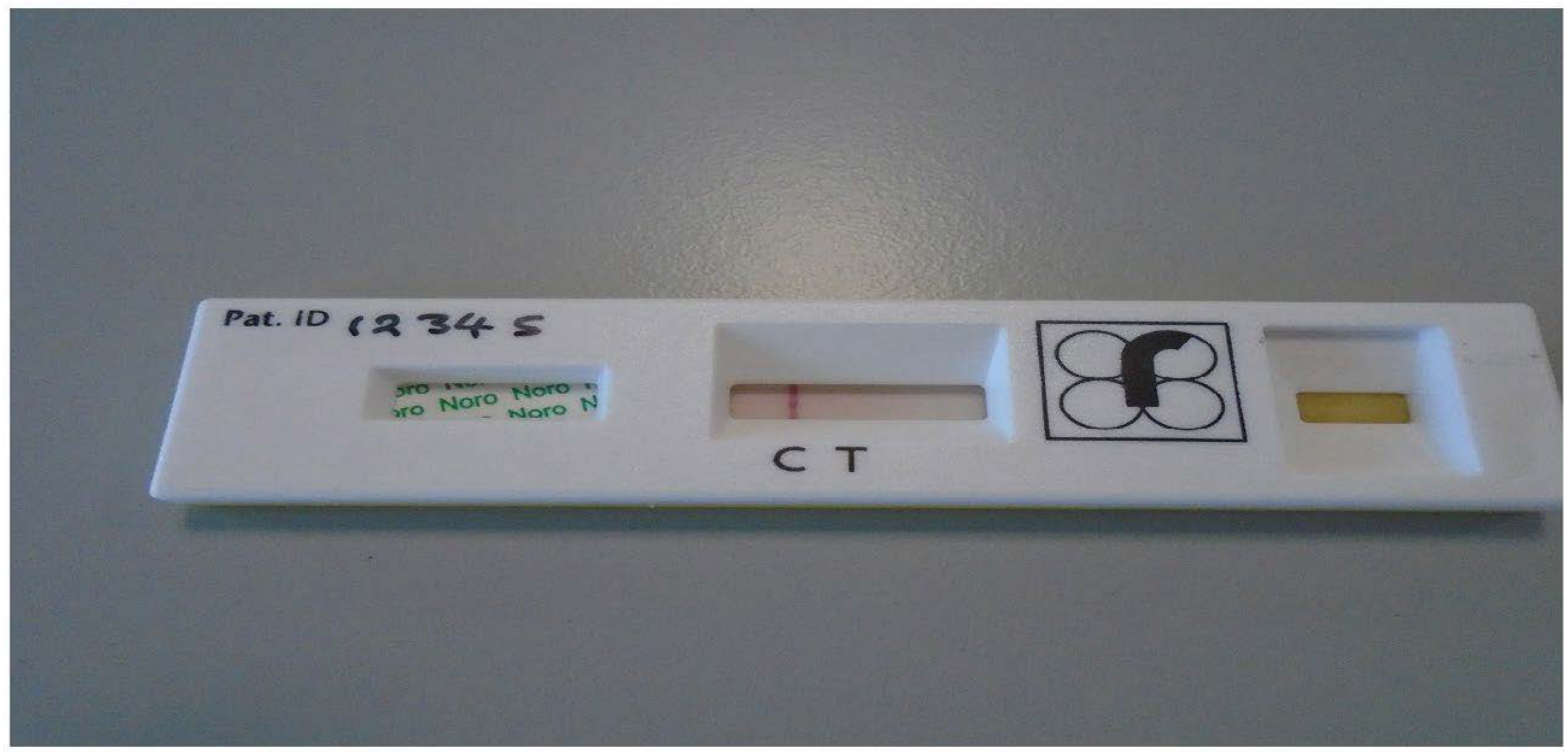

\section{References}

[1] Gest H. The discovery of microorganisms by Robert Hooke and Antoni van Leeuwenhoek, Fellows of The Royal Society. Notes Rec Roy Soc. 2004;58:187-201.

http://dx.doi.org/10.1098/rsnr.2004.0055.

[2] Lederberg J. Infectious history. Science. 2000;288:287-293.

[3] Monath TP. Yellow fever: Victor, Victoria? Conqueror, conquest? Epidemics and research in the last forty years and prospects for the future. Am J Trop Med Hyg. 1991;45:1-43.

[4] Pitt SJ. Managing for quality in clinical microbiology services [dissertation]. Liverpool: Liverpool John Moores University; 2001. 
[5] de Martel C, Ferlay J, Franceschi S, et al. Global burden of cancers attributable to infections in 2008: a review and synthetic analysis. Lancet Oncol. 2012;13:607-

615. http://dx.doi.org/10.1016/S1470-2045(12)70137-7.

[6] Vivancos R, Keenan A, Farmer S, et al. An ongoing large outbreak of measles in Merseyside, England, January to June 2012. Euro Surveill. 2012;17:20226. Available from: http://www.eurosurveillance.org/ViewArticle. aspx?Articleld=20226.

[7] Ott JJ, Stevens GA, Groeger J, et al. Global epidemiology of hepatitis B virus infection: new estimates of age-specific HBsAg seroprevalence and endemicity. Vaccine. 2012;30:2212-2219. http://dx.doi.org/10.1016/j.vaccine. 2011.12.11.

[8] Public Health England [Internet]. London: Public Health England. [Cited 2016 Sep 29]. Available from: https://www. gov.uk/topic/health-protection/infectious-diseases.

[9] Public Health Wales Health Protection Division [Internet]. Cardiff: Public Health Wales. [Cited 2016 Sep 29]. Available from: http://www.wales.nhs.uk/sites3/home. cfm?orgid=457.

[10] Health Protection Scotland [Internet]. Glasgow: Health Protection Scotland. [Cited 2016 Sep 29]. Available from: http://www.hps.scot.nhs.uk/index.aspx.

[11] Public Health Agency Northern Ireland [Internet]. Belfast: Health and Social Care Northern Ireland Public Health Agency. [Cited 2016 Sep 29]. Available from: www.

publichealth.hscni.net/directorate-public-health/health-protection.

[12] Public Health England: Hepatitis C in the UK [Internet]. London: Public Health England. [Cited 2016 Sep 30].

[13] Available from: https://www.gov.uk/government/publications/hepatitis-c-in-the-uk.

[14 Public Health England: HIV in the UK - Situation Report 2015 [Internet]. London: Public Health England. [Cited 2016 Sep 30]. Available from: https://www.gov.uk/government/statistics/hivin-the-united-kingdom.

[15] World Health Organisation: Ebola Virus Disease [Internet]. Geneva: World Health Organisation. [Cited 2016 Sep 30]. Available from: http://www.who.int/ebola/en/.

[16] Broadhurst MJ, Kelly JD, Miller A, et al. ReEBOV Antigen Rapid Test kit for point-of-care and laboratory-based testing for Ebola virus disease: a field validation study. Lancet. 2015;386:867-874. http://dx.doi.org/10.1016/S0140-6736(15)61042-X.

[17] Ashley RL. Laboratory techniques in the diagnosis of herpes simplex infection. Genitourin Med. 1993;69:174.

[18] Coffin SE, Hodinka RL. Utility of direct immunofluorescence and virus culture for detection of varicella-zoster virus in skin lesions. J Clin Microbiol. 1995;33:2792-2795.

[19] Vinjé J. Advances in laboratory methods for detection and typing of norovirus. J Clin Microbiol. 2015;53:373-381.

[20] Porter HJ, Khong TY, Evans MF, et al. Parvovirus as a cause of hydrops fetalis: detection by in situ DNA hybridisation. J Clin Pathol. 1988;41:381-383. 
[21] De Villiers EM, Schneider A, Miklaw H, et al. Human papillomavirus infections in women with and without abnormal cervical cytology. Lancet. 1987;330:703-706.

[22] Mullis K, Faloona F, Scharf S, et al. Specific enzymatic amplification of DNA in vitro: the polymerase chain reaction. Cold Spring Harbor Symposia Quant Biol. 1986;51:263-273.

[23] Mullis KB. The unusual origin of the polymerase chain reaction. Sci Am. 1990;262:56-65.

[24] Evans PC, Gray JJ, Wreghitt TG, et al. Comparison of three PCR techniques for detecting cytomegalovirus (CMV) DNA in serum, detection of early antigen fluorescent foci and culture for the diagnosis of CMV infection. J Med Microbiol. 1999;48:1029-1035.

[25] Cherian T, Bobo L, Steinhoff MC, et al. Use of PCR-enzyme immunoassay for identification of influenza A virus matrix RNA in clinical samples negative for cultivable virus. J Clin Microbiol. 1994;32:623-628.

[26] Liolios L, Jenney A, Spelman D, et al. Comparison of a multiplex reverse transcription-PCRenzyme hybridization assay with conventional viral culture and immunofluorescence techniques for the detection of seven viral respiratory pathogens. J Clin Microbiol. 2001;39:2779-2783.

Elnifro EM, Ashshi AM, Cooper RJ, et al. Multiplex PCR: optimization and application in diagnostic virology. Clin Microbiol Rev. 2000;13:559-570.

[27] Anderson TP, Werno AM, Barratt K, et al. Comparison of four multiplex PCR assays for the detection of viral pathogens in respiratory specimens. J Virol Methods. 2013;191:118-121.

[28] Jansen RR, Schinkel J, Koekkoek S, et al. Development and evaluation of a four-tube real time multiplex PCR assay covering fourteen respiratory viruses, and comparison to its corresponding single target counterparts. J Clin Virol. 2011;51:179-185.

[29] L ogan C, O'Leary JJ, O'Sullivan N. Real-time reverse transcription-pcr for detection of rotavirus and adenovirus as causative agents of acute viral gastroenteritis in children. J Clin Microbiol. 2006;44:3189-3195.

[30] Papadakis G, Chibo D, Druce J, et al. Detection and genotyping of enteroviruses in cerebrospinal fluid in patients in Victoria, Australia, 2007-2013. J Med Virol. 2014;86:1609-1613.

[31] Hawrami K, Breuer J. Development of a flurogenic polymerase chain reaction assay (TaqMan) for the detection and quantitation of varicella zoster virus. J Virol Methods. 1999;79:3340.

[32] Ward CL, Dempsey MH, Ring CJA, et al. Design and performance testing of quantitative real time PCR assays for influenza A and B viral load measurement. J Clin Virol. 2004;29:179-188.

[33] Sarrazin C, Shiffman ML, Hadziyannis SJ, et al. Definition of rapid virologic response with a highly sensitive real-time PCR-based HCV RNA assay in peginterferon alfa-2a plus ribavirin responseguided therapy. J Hepatol. 2010;52:832-838.

Atabani SF, Smith C, Atkinson C, et al. Cytomegalovirus replication kinetics in solid organ transplant recipients managed by preemptive therapy. Am J Transplant. 2012;12:2457-2464.

[34] Stockton J, Ellis JS, Saville M, et al. Multiplex PCR for typing and subtyping influenza and respiratory syncytial viruses. J Clin Microbiol. 1998;36:2990-2995. 
[35] Morter S, Bennet G, Fish J, et al. Norovirus in the hospital setting: virus introduction and spread within the hospital environment. J Hosp Infect. 2011;77:106-112.

[36] Alavian SM, Carman WF, Jazayeri SM. HBsAg variants: diagnostic-escape and diagnostic dilemma. J Clin Virol. 2013;57:201-208.

[37] Erdman DD, Anderson LJ, Adams DR, et al. Evaluation of monoclonal antibody-based capture enzyme immunoassays for detection of specific antibodies to measles virus. J Clin Microbiol. 1991;29:1466-1471.

[38] Mimms L, Goetze A, Swanson S, et al. Second generation assays for the detection of antibody to HBsAg using recombinant DNA-derived HBsAg. J Virol Methods. 1989;25:211-231.

Brust S, Duttmann H, Feldner J, et al. Shortening of the diagnostic window with a new combined HIV p24 antigen and anti-HIV-1/2/O screening test. J Virol Methods. 2000;90:153-165.

http://dx.doi.org/10.1016/S0166-0934

(00) $\quad 00229-9$.

[41] Gray JJ, Kohli E, Ruggeri FM. European multicenter evaluation of commercial enzyme immunoassays for detecting norovirus antigen in fecal samples. Clin Vaccine Immunol. 2007;14:1349-1355.

[42] Blacksell SD, Jarman RG, Bailey MS, et al. Evaluation of six commercial point-of-care tests for diagnosis of acute dengue infections: the need for combining NS1 antigen and IgM/IgG antibody detection to achieve acceptable levels of accuracy. Clin Vaccine Immunol. 2011;18:2095-2101.

[43] Hurt AC, Alexander R, Hibbert J, et al. Performance of six influenza rapid tests in detecting human influenza in clinical specimens. J Clin Virol. 2007;39:132-135.

[44] Skidmore S, Horner P, Mallinson H. Testing specimens for Chlamydia trachomatis. Sex Transm Infect. 2006;82:272-275.

[45] Barzon L, Lavezzo E, Costanzi G, et al. Next-generation sequencing technologies in diagnostic virology. J Clin Virol. 2013;58:346-350.

[46] Quiñones-Mateu ME, Avila S, Reyes-Teran G, et al. Deep sequencing: becoming a critical tool in clinical virology. J Clin Virol. 2014;61:9-19.

[47] Gibson RM, Schmotzer CL, Quiñones-Mateu M E. Next-generation sequencing to help monitor patients infected with HIV: ready for clinical Use? Curr Infect Dis Rep. 2014;16:1-9.

[41] Thomson E, Ip CL, Badhan A, et al. Comparison of next generation sequencing technologies for the comprehensive assessment of full-length hepatitis C viral genomes. J Clin Microbiol. 2016; JCM-00330.

[42] Blumberg BS. Hepatitis B virus, the vaccine, and the control of primary cancer of the liver. Proc Natl Acad Sci USA. 1997;94:7121-7125.

[43] Dane DS, Cameron CH, Briggs M. Virus-like particles in serum of patients with Australiaantigen-associated hepatitis. Lancet. 1970;295:695-698.

[44] Cossart YE, Cant B, Field AM, et al. Parvovirus-like particles in human sera. Lancet. $1975 ; 305: 72-73$. 
Barre-Sinoussi FS, Chermann JC, Rey F, et al. Isolation of a T-lymphotropic retrovirus from a patient at risk for acquired immune deficiency syndrome (AIDS). Science. 1983;220:868-871.

[45] Hill WM. Are echoviruses still orphans? Brit J Biomed Sci. 1996;53:221-226.

[46] Choo QL, Kuo G, Weiner AJ, et al. Isolation of a cDNA clone derived from a blood-borne nonA, non-B viral hepatitis genome. Science. 1989;244:359-362.

[47] Kuo G, Choo QL, Alter HJ, et al. An assay for circulating antibodies to a major etiologic virus of human non-A, non-B hepatitis. Science. 1989;244:362-364.

[48] A Iter H. Discovery of non-A, non-B hepatitis and identification of its etiology. Am J Med. 1999;107:16-20.

[49] Zaki AM, van Boheemen S, Bestebroer TM, et al. Isolation of a novel coronavirus from a man with pneumonia in Saudi Arabia. New Engl J Med. 2012;367:1814-1820.

[50] WHO MERS-CoV Research Group. State of knowledge and data gaps of Middle East respiratory syndrome coronavirus (MERS-CoV) in humans. PLOS Curr Outbreaks. 2013. http://dx.doi.org/10.1371/currents.outbreaks.0bf19e352e 7478f8ad85fa30127ddb8

[51] Weller SA, Bailey D, Matthews S, et al. Evaluation of the Biofire FilmArray BioThreat-E Test (v2.5) for rapid identification of ebola virus disease in heat-treated blood samples obtained in Sierra Leone and the United Kingdom. J Clin Microbiol. 2016;54:114-119.

[52] Fenner F. Global eradication of smallpox. Rev Infect Dis. 1982;4:916-930.

Morens DM, Holmes EC, Davis AS, et al. Global rinderpest eradication: Lessons learned and why humans should celebrate too. J Infect Dis. 2011;204:502-505.

[53] Global Polio Eradication Initiative[Internet]. Geneva: World Health Organization Global Polio Eradication Initiative; [cited 2015 Sep 14]. Available from: http://www. polioeradication.org.

[54] Measles and Rubella [Internet]. Copenhagen: World Health Organization Regional Office for Europe. Available from: http://www.euro.who.int/en/health-topics/communicablediseases/measles-and-rubella.

[55] Biosure HIV Self Test [Internet]. Nazeing: Biosure (UK) Ltd. [Cited 2016 Sep 21]. Available from: http://hivselftest. co.uk. 